\title{
Diálogos e perspectivas: a presença das mulheres nas enchentes do Pantanal em Porto Murtinho
}

Ilsyane do Rocio Kmitta* André Cândido da Silva**

Resumo: O propósito deste artigo é apresentar os discursos que se refere à representação das mulheres nas enchentes do Pantanal, em especial, no município de Porto Murtinho/MS, na fronteira com o Paraguai, no período que abrange as décadas de 1970 a 1990, relacionando com as concepções sobre a história das mulheres com a categoria gênero, em meio às práticas sociais e culturais. O presente trabalho tem como a sua fonte de pesquisa primária as Fontes Orais, fator predominante para abordar a história de vida das mulheres, seus silêncios e resistências. A proposta inicial deste artigo foi contemplar a presença das mulheres, sua relação com o meioambiente, seu cotidiano e as privações no período das enchentes em Porto Murtinho.

Palavras-chave: Mulheres; Gênero; Representação.

Abstract: The purpose of this article is to present the speeches referred to the representation of women in the Pantanal's flood, especially in the municipality of Porto Murtinho/MS, on the border of Paraguay, during 1970s to 1990s, related with conceiving about women's history with the gender category and its social and cultural practices. The present article uses oral sources as the manly way to access those women's lives, their silences and resistances. The initial purpose of this article was contemplating the presence of women, their relationship with the environment, their daily lives and hardships during the floods in Porto Murtinho.

Keywords: Women; Gender; Representation.

\footnotetext{
* Mestre em História da Universidade Federal de Dourados. Doutorado em andamento na Universidade Federal de Dourados.

** Mestrado em andamento na Universidade Federal de Dourados.
} 
Cidade situada às margens do Rio Paraguai, cerca de $50 \mathrm{~km}$ a montante do Rio Apa, Porto Murtinho iniciou sua trajetória em meados de 1850, no local conhecido como "Fecho dos Morros”. Em 1912 ocorreu a instalação do município, constituído basicamente por moradores vindos do sul devido à produção da erva-mate, de índios e paraguaios que já viviam no local, imigrantes europeus, árabes e judeus atraídos pelo comércio, que aos poucos despontava, aliado a extração da erva-mate. Fator este que está estritamente ligado ao intuito de desbravamento, conquista e incorporação de terras o que corresponde ao alargamento das fronteiras e o desenvolvimento da economia de caráter exportador, podendo ser aqui caracterizado como "um dos fatores derivados do movimento irradiador das relações capitalistas.” (CORRÊA, 1999:147) Assim, a exploração de vastas extensões gerava deslocamentos tanto internos quanto externos, que por sua vez, abriam a possibilidade de exploração e redefinição dos espaços fronteiriços. Portanto, a formação cultural de seu povo está estritamente ligada às imigrações que se seguiram no decorrer da constituição do município e ocorrem ainda hoje, por se tratar de uma região fronteiriça.

Fronteira essa onde hábitos e costumes diversos se fundem dando origem a um amalgama cultural que envolve índios, paraguaios, imigrantes e o pantaneiro que junto às populações ribeirinhas difunde as práticas e costumes, os “causos", os mitos, as superstições e as lendas que rondam seu universo mítico. Em suas análises, Lúcia Salsa Corrêa ressalta que "um dos efeitos principais da guerra da Tríplice Aliança em solo mato-grossense foi à contribuição da grande migração paraguaia, fenômeno de efeito marcante na formação econômica, social e cultural do Sul do Mato Grosso" (CORRÊA, 1999: 147). É possível perceber que a população já incorporou a cultura paraguaia que se faz presente nas datas festivas como a Festa de Nossa Senhora de Caacupê. A proximidade com o Paraguai através da Colônia Peralta e Ilha Margarida, contribui significativamente para este sincretismo cultural e estão aliadas as origens de sua colonização voltada para a vastidão territorial e a exploração das suas riquezas naturais.

No Pantanal de Nabileque e de Porto Murtinho, as enchentes atingem sua capacidade máxima entre maio e junho, quando as águas do Rio Paraguai se elevam ocasionando as cheias. Por ser em períodos alternados de cheias e estiagem, a população urbana e ribeirinha aprendeu a conviver com estes ciclos climáticos e faz uma leitura deles de forma que lhe propiciem a continuidade das atividades ali desenvolvidas. Constroem com este ambiente uma relação de interação e assimilação de costumes e leitura da natureza consolidados no cotidiano. Basicamente todas as mudanças e as transformações estão associadas à natureza, 
como por exemplo, a pesca e o turismo. Quando o nível das águas sobe, atinge as populações urbana e ribeirinha que encontram nos jiraus o recurso para "passar" pela enchente. Constatamos que muitas famílias quando na ocorrência das enchentes de 1979 e 1982, não acreditavam que seria uma grande enchente. Sabiam da quantidade de chuva, mas não acreditavam na possibilidade de ocorrer uma grande enchente.

É através das narrativas que ingressamos no fascínio das experiências do vivido destes grupos. A possibilidade do contato com estas pessoas é algo fundamental para a proximidade com o passado através de seus relatos. Quanto à natureza deste fascínio proporcionado pela história oral, Verena Alberti escreve que "quando isso acontece é porque nela encontramos a 'vivacidade' do passado, a possibilidade de revivê-lo pela experiência do entrevistado." (2004:15)

A escolha das fontes orais como fonte primária da pesquisa buscou valorizar e incorporar a memória da população murtinhense, considerando não apenas os fatos, mas os anseios, crenças, desejos, e as representações que permeiam esta memória. Alberti salienta que "a História oral é hoje um caminho interessante para se conhecer e registrar múltiplas possibilidades que se manifestam e dão sentido as formas de vida e escolhas de diferentes grupos sociais, em todas as camadas da sociedade" (2005: 164).

A história oral empreende a investigação das memórias tendo que enfrentar necessariamente a questão da subjetividade. Buscamos auxilio em Pollak para sublinhar o problema da subjetividade e das fontes. Para o autor, "até as mais subjetivas das fontes, tais como uma história de vida individual podem sofrer uma critica, por cruzamento de informações obtidas a partir de fontes diferentes" (1992: 200).

Pautamos aqui que uma entrevista de história oral deve estar regulada em princípios éticos, e que diferença e igualdade, sinceridade e respeito (PORTELLI, 1997: 13-18) são conceitos significativos no desenvolvimento de pesquisas que se utilizem de fontes orais. $\mathrm{O}$ que significa dizer que a narrativa oral, viabiliza o esclarecimento de trajetórias individuais por dar atenção à história do cotidiano e da vida privada, de valorizar a sua própria visão de mundo e do grupo social ao qual pertencem, por visar à história local e enraizada e por ter a história do tempo presente como perspectiva temporal. Desta forma, possibilita que indivíduos pertencentes a diferentes categorias sociais possam se expressar, deixando estes registros para as mais variadas análises seja nesta pesquisa quanto em trabalhos futuros.

Estamos então, neste caso, frente à questão, que rememorar não é o mesmo que viver novamente o passado, que juntar fragmentos que a muito estão depositados na estante das 
reminiscências com nuances individuais ou de um grupo, mas sim uma atividade do presente com significados e implicações diretas no cotidiano dos moradores, aqui mais especificamente das mulheres.

A memória é "deslocável, móvel, sem lugar fixo", conforme afirma Michel de Certeau. Segundo ele, "longe de ser o relicário ou a lata de lixo do passado, a memória vive de crer nos possíveis, e de esperá-los vigilante, à espreita" (CERTEAU, 2001: 163). Assim, partilhamos da ideia de Michel Pollak ao dizer que "a memória é seletiva. Nem tudo fica gravado. Nem tudo fica registrado" (1992: 203). Contudo, segundo o autor, a memória é construída socialmente, e os modos desta construção podem ser tanto conscientes quanto inconscientes, portanto, não estão condicionadas ao passado, suas arestas são lapidadas pelo presente onde são resignificadas e atendem a interesses sejam estes individuais ou do grupo.

Nas entrevistas realizadas, percebemos uma participação considerável, significativa da mulher em momentos decisivos no que se refere à família e uma diferenciação no que tange sua relação com a natureza. São observações minuciosas dos fatos e apontam para resistências como em abandonar suas casas no período das cheias, para instalar a família no acampamento provisório. Essas mulheres têm em suas mãos a vida privada da família e cabe a elas tal decisão. Muitas, no entanto, chegam ao seu limite de resistência onde a simples ideia de expor sua privacidade é sinônimo de resistências.

Nessa perspectiva, a história social e cultural vem contribuir para o desenvolvimento e estudos sobre as mulheres, apresentando um grande número de abordagens que ultrapassam as fronteiras do conhecimento histórico, tais como: sexualidade, corpo, imaginário, relações sociais, ambiente público e privado, controle, poder, representações, entre outros enfoques que abrange esse objeto de estudo e alcança o campo da interdisciplinaridade. Por esse viés, acreditamos que Certeau apresenta uma contribuição significante quando o autor analisa que “toda pesquisa historiográfica se articula com um lugar de produção sócio-economico, político e cultural.” (CERTEAU, 1982: 66).

Nesse sentido se considerarmos que ao longo da nossa historiografia, temos a mulher esquecida dos textos históricos ou então figurando como meros coadjuvantes da ação masculina percebemos que em se tratando da associação da mulher a elementos da natureza, seu papel é sempre o oposto da força, caracteriza-se como frágil e estática figurando como o lado negativo. A figura feminina é associada à água estagnada e submissa, passiva. Associada as feiticeiras portadoras de conhecimentos capazes de domar os próprios elementos da natureza, figura, no entanto, não benéfica e causa medo nos homens. É pertinente fazer 
referencia aqui, ao artigo escrito por Lucia Tosi "Mulher e Ciência" quando escreve que no final do século XV a demonização da mulher passa por mudanças drásticas. A autora salienta:

Afirmava-se que dada sua fraqueza física e moral, sua limitada inteligência, sua carência de raciocínio, sua sexualidade incontrolável e sua lubricidade, a mulher era a vítima privilegiada de Satã. Seu saber e seus misteriosos poderes só podiam ter sido adquiridos por meios ilícitos, pactuando com o demônio (TOSI, 1998: 369).

Ao escrever sobre a mulher popular rebelde, no subtítulo "as mulheres, águas paradas", Perrot chama a atenção para a repetição de mitos envolvendo a mulher no século XIX, tomando de empréstimo elementos associativos da natureza. Notemos a permanência dos valores do século XV, vigentes no século XIX. Para a autora,

Ora a mulher é fogo, devastadora de rotinas familiares e da ordem burguesa, devoradora, consumindo as energias viris, mulher das febres e das paixões românticas, que a psicanálise, guardiã da paz nas famílias, colocará na categoria das neuróticas; filha do diabo, mulher louca, histérica, herdeira das feiticeiras de outrora (PERROT, 1988: 181).

Em Diegues, encontramos ideia similar quando o autor descreve a associação da mulher as águas, no que tange as práticas sociais, culturais e simbólicas em comunidades de pescadores. Símbolos estes, por deveras, construídos em espaços marcados pela imprevisibilidade. Para o autor,

Os rios e lagoas dão origem a imagens e símbolos, em grande parte, distintos daqueles associados aos mares [...] as imagens associadas às torrentes e rios referem-se à água doce, com suas características femininas, passo que o mar, em grande parte das mitologias está associado ao masculino (DIEGUES, 2000: 5).

Adjetivos estes por deveras reforçados, presentes no imaginário de comunidades de pescadores que associam o feminino a lagoa e o masculino ao mar. Não podemos negar à pertinência de tal colocação que é em parte, interessante considerando-se os múltiplos significados atribuídos as águas. Temos a água como uma das condições básicas para a reprodução dos organismos vivos e, que ao mesmo tempo, "se inscreve no domínio do simbólico, enfeixando várias imagens e significados.” (CUNHA, 2005:15) Neste contexto, prossegue a autora, “a água está, assim, na natureza, e a um só tempo, na cultura. Está nos mitos e na história." (2005:16) A imagem da mulher no que se refere à natureza, simbolicamente está associada à água doce, lacustre, estagnada, sugere a ideia de passividade. 
A identificação da mulher com a natureza e o homem com a cultura está atrelado ao ponto de vista político do pensamento ocidental. A cultura emerge como superior a natureza. Para Sherry Ortner, categorias como cultura e natureza são conceituais e "que cada cultura reconhece e mantém implicitamente uma distinção entre a atuação da natureza e a atuação da cultura" (1979: 98). É importante salientar que "as mulheres são identificadas ou simbolicamente associadas com a natureza, em oposição aos homens que são identificados com a cultura". Isso posto, acrescenta a autora uma vez que o plano de cultura é submeter e transcender a natureza [“...] então a cultura achará "natural” subordiná-las, para não dizer oprimi-las”. (ORTNER, 1979: 101-102) Encontramo-nos aqui diante de uma questão que pede cautela. Muitas das associações são históricas e deterministas. São detentoras de valores estereotipados, construídos historicamente e socialmente. Questão esta que, segundo Marcos Montysuma,

Tanto as mulheres quanto os homens são verdadeiramente pressionados a suportar a imposição de determinados códigos sociais, como algo que pode até advir de componentes da diferenciação sexual, situados na instância biológica, que como tal é tomada como referência justificadora, mas na verdade são construídos e incorporados pelos sujeitos (2008: 2)

Em conformidade com o autor, estas concepções são construídas a partir da sexualidade, ao longo de um processo, onde as mesmas se alteram e se modificam. Nesse sentido, a compreensão e a necessidade de desconstruir tais concepções permitem uma maior interação cultural e de valores. As representações e as práticas cotidianas, tanto podem ser positivas quanto negativas em se tratando de gênero, que surge como uma construção a partir destas representações. Portanto, a mulher não poderá apenas ter uma associatividade com a natureza ante o fato de que "tendo consciência, ela pensa e fala: ela gera, comunica e manipula símbolos, categorias e valores”. (MONTYSUMA, 2008:2) Perspectiva essa, que nos conduz aos estudos de Michelle Perrot (2005) e sua participação nas pesquisas sobre as mulheres, desenvolvendo trabalhos no âmbito da história, cujos debates giram em torno da ausência das mulheres, suas resistências e representações na narrativa historiográfica feita pelos homens "que foram, por muito tempo, os únicos historiadores." (COLLING,2014:21)

Seguindo essa perspectiva de análise, o autor Roger Chartier (1991), afirma que o entendimento do mundo e da sociedade é construído por meio das representações da cultura social em relação com o coletivo. Ainda, segundo o autor, são "as representações impostas pelo que detêm o poder de classificar e de nomear e a definição, de aceitação ou de resistência, que cada comunidade produz de si mesma" (CHARTIER, 1991: 183). O autor 
expõe as evidencias que essa complexidade permite categorizar os signos prováveis ou estabelecidos, diferente do que é realmente representado, ou, ao menos a tentativa de representá-lo, identificando em condições necessárias em relação conhecimento dos signos, como questão fundamental e compreensível da representação. Para o autor, as representações possuem variações e categorização em conformidade com o grupo que as produziu, portanto, são sempre determinadas pelos interesses que as forjaram, mediadas ora pelo poder, ora pela dominação. E, não sendo portadoras de discursos neutros, são legitimadoras de escolhas seja no campo da concorrência, seja no campo das lutas de representações.

Ademais, se as representações sociais permitem questionar a relação do individuosociedade, onde o mesmo enquanto detentor de conhecimento estabelece relações e elabora representações partilhadas socialmente, levando ao reconhecimento de suas lutas, vemos que as "as estratégias simbólicas que determinam posições e relações e constroem, para cada classe, grupo ou meio, uma percepção de si constitutiva da sua identidade" (Chartier, 1991) podem interferir na elaboração das representações e subjetividades nos mais variados níveis tanto social quanto culturalmente atuando como elementos definidores de identidades e da interação nos espaços públicos e sociais. Portanto,

as operações de recorte e de classificação que produzem as configurações múltiplas graças às quais a realidade é percebida, construída, representada; em seguida, os signos que visam a fazer reconhecer uma identidade social, a exibir uma identidade própria de estar no mundo, a significar simbolicamente um estatuto, uma ordem, um poder; enfim, as formas institucionalizadas através das quais 'representantes' encarnam de modo visível, 'presentificam', a coerência de uma dada comunidade, a força de uma identidade, ou a permanência de um poder (CHARTIER, 2002, p. 169).

Seguindo essa ótica de análise, entendemos que é necessário abordar a importância de como os estudos de gênero tem contribuído de forma relevante para a história contemporânea, tirando a mulher da invisibilidade do meio social, possibilitando o crescimento e articulação com a história das mulheres frente a uma desigualdade em relação ao sexo e da análise sobre essas diferenças. Em conformidade com Ana Colling "os discursos contemporâneos parecem explicitar o fato de que os processos históricos não progridem de forma linear, mas despontam em sentidos marginais", e para a autora, os mesmos vem "revelando uma pluralidade de regras e comportamentos que traduzem os múltiplos contextos nos quais os homens e as mulheres se imbricam.” (2014:14) 
Em relação ao termo "gênero", Joan Scott defende que a definição concentra-se na produção das identidades, condicionados a uma circunstância equivalente aos sentidos e necessidades de interesse, tanto por parte dos sujeitos individuais quanto ao coletivo, constituindo uma perspectiva de noção de experiência, ou seja, "para la identidad política, como las instituciones sociales y para los símbolos culturales, la política feminista es una forma de produción del conocimiento” (SCOTT, 2008: 24).

Desse modo, utilizar o conceito de gênero em uma perspectiva de análise histórica ainda perpassa por vários enfrentamentos em relação a uma compreensão das questões teóricas, tratando-se de ações em meio às práticas políticas que registram alguns movimentos sociais, em especial, os movimentos feministas, ocasionando um amplo questionamento e debates sobre as práticas políticas de dominação e submissão. Para Colling, os discursos atuam como lentes, cuja leitura apresenta que "as mulheres, assim como os homens, são simplesmente um efeito de práticas discursivas e não discursivas.” (2014:34)

Um dos clássicos trabalhos de Joan Scott, a autora apresenta a seguinte afirmação:

Uma maneira de indicar "construções sociais"- a criação inteiramente social de idéias sobre papéis adequados aos homens e às mulheres. É uma maneira de se referir às origens exclusivamente sociais das identidades subjetivas dos homens e das mulheres. O gênero é, segundo essa definição, uma categoria social imposta sobre o corpo sexuado (SCOTT, 1995: 75).

A autora vai fomentar questões relacionadas à ruptura paradigmáticas no campo histórico e sociológico, utilizando-se abordagens no campo histórico, na qual, serão levantadas para expor problemas relacionadas à construção de identidades, gênero e história, colocando em questionamentos a essa possível categoria ligada ao feminismo mediante a política. A construção do pensamento e legitimação da categoria de gênero será enfatizada pela autora mediante a sua preocupação com as formas e estruturas relacionadas às concepções culturais e pós-estruturalistas, enfatizando os significados e a necessidade da compreensão para os processos discursivos mediante as práticas normativas sociais, presentes na política e dominação social.

Voltemos aqui, para a associação da mulher as águas. A passividade contida nesta associatividade não é condizente, frente às narrativas das mulheres e suas experiências no período das águas em Porto Murtinho. Estas mulheres quebram estas construções estabelecidas historicamente. São portadoras de força diante de uma situação problema e, atuam enquanto um elemento modificador, que em nada aponta para a passividade. Ao 
entrelaçar memórias e intimidades, dão a estas, significados e permitem mediar sua relação com a natureza, mas no sentido de renascimento. No Pantanal, o ciclo das águas é sinal de renovação, reaviva os ecossistemas. A água dá vida, traz a certeza de um período de fartura para a região. O nascimento de um filho, para estas mulheres é de certa forma, o renascer para a vida, diante de uma situação que exige força e dinamismo.

A presença das mulheres, no período das enchentes em Porto Murtinho, demonstra a real capacidade que as mesmas têm enquanto participes de um espaço complexo e singular de relações que englobam diversos fatores, é o romper os elos de uma cadeia socialmente articulada. Muitas das mulheres entrevistadas demonstram que as características associadas ao feminino têm a preocupação relevante de manter tais "estereótipos" socialmente construídos. No entanto, muitas destas mulheres "teimam em andar na contramão", cientes de suas possibilidades e da capacidade de promover mudanças.

Este é o caso de Dona Norma que contrária às condições a ela impostas, aos 14 anos decide mudar o rumo de sua história. Além de estudar, ela trabalhava e desenvolveu muitas atividades voltadas ao comércio, dentre ela a cubicar madeira, atividade esta atribuída como "serviço de homem". Esta mulher, aparentemente muito simples, fala fluentemente três línguas, segundo ela mesma conta: "Falo, português, espanhol que é a língua que aprendi com minha mãe (...) aprendi na adolescência o guarani (...) com os trabalhos que eu fiz com os indígenas eu fui aprendendo o caiuá” (PEREIRA, 2008).

As surpresas não param por aí, ao falar sobre a necessidade que teve de deixar a cidade para que suas duas filhas pudessem estudar, descobre que pode alçar voos mais ousados. Enquanto fala, sorri satisfeita pelo caminho percorrido, pelos obstáculos que soube desviar para atingir objetivos pautados nas necessidades imediatas, mas nem por isso, menos valorados. Assim ela acrescenta: "Saí por quatro anos por assim, então, pra poder formar minhas filhas, pra poder ganhar mais, tive que sair daqui. Até foi bom pra mim porque eu fui vê que eu tinha muito valor pra lá, fora daqui." Ela deixou Porto Murtinho e foi a Tacuru e Paranhos, e pelo fato de falar línguas indígenas, trabalhou na prefeitura de Paranhos, na área social e na orientação para a preservação do meio ambiente, por um período de seis anos. Dizse ambientalista até o ultimo, e nas suas lutas constantes, defende a preservação do Rio Paraguai, devido à grande quantidade de lixo deixada pelos barcos de turismo.

Esta mulher que começou a trabalhar aos 14 anos como vendedora, trabalhou na área social e ambiental, volta a Porto Murtinho, trabalha no cartório, no fórum, busca leituras que auxiliem no bom desempenho de suas funções e aprofunda seus conhecimentos sobre os 
muitos assuntos que envolvem a região. É aprovada em concurso publico e tempos depois é eleita a primeira conselheira tutelar da cidade e assim segue por dois mandatos. Uma nova fase que exige da mesma muita dedicação face aos percalços, todos associados ao fato de ser uma mulher, mas que classifica como uma experiência positiva, mesmo tendo que lidar com a questão da prostituição que despontava no município associada ao turismo.

Esta é apenas uma das muitas faces de mulheres que enfrentaram sem medo, os entraves a elas impostos, com o intuito de buscar uma melhoria na sua condição de vida. Mulheres que não aceitaram passivamente uma história escrita por seus pais e familiares, ou mesmo pela sua condição social. Segundo Saffioti ao discutir a participação da mulher enquanto agente participante e modificador na esfera social que assinala, não consiste ainda em valor, "ter um emprego significa, para a mulher, encontrar um modo socialmente aceitável de enfrentar uma situação econômica difícil ou de ampliar os rendimentos da família, de maneira a permitir certa folga orçamentária [...]" (SAFFIOTI, 1976: 300). Não podemos deixar de mencionar que na década de 50, segundo Bassanezi, há um crescimento significativo da inserção feminina no mercado de trabalho, mais especificamente nos setores de serviços como, por exemplo, professoras, enfermeiras, serviço publico dentre outros. No entanto, prossegue a autora, "eram nítidos os preconceitos que cercavam o trabalho feminino nesta época" (BASSANEZI, 2004: 624). Este preconceito é advindo, porque as mulheres, “eram vistas prioritariamente como donas de casa e mães", ou seja, no bojo imaginário social havia incompatibilidade entre o trabalho feminino, o casamento e a maternidade.

Quando a mulher insiste pela inserção no mercado de trabalho, busca uma melhora orçamentária, isso posto porque geralmente, esta melhoria orçamentária estava associada às condições impostas socialmente e diretamente ligadas a educação dos filhos ou a aquisição de bens, que dispendia de valores nem sempre suficientemente advindos do trabalho do homem, portanto, este trabalho feminino até certo ponto e ainda segundo a autora, "pode ser visto como um mecanismo de manutenção do status econômico do grupo familial ou como mecanismo coadjutor no processo de ascensão social” (SAFFIOTI, 1976: 301). Portanto, o trabalho feminino está intimamente associado à melhoria da qualidade de vida no âmbito familiar.

As mudanças estruturais e conceituais da sociedade são influenciadas pela cultura, que por sua vez está inclusa nos processos de socialização formadores de identidades. As especificidades que o individuo ou o grupo conserva em seu interior, são niveladores das relações ou da reelaboração das mesmas. Este é o caso de Ninfa Avelar, que hesitou em 
mudar alguns aspectos que cerceavam sua vida. Naturalizada brasileira aos 11 anos, esta mulher de origem paraguaia, desde a mais tenra infância enfrentou as dificuldades impostas pelo meio para estudar. Ela nos conta que

Tinha que lavar ropa, tinha que fazer muita coisa, eu tive 12 irmãos sabe, na época, tudo escadinha e eu era a mais velha da turma e tinha que ajudar a minha mãe. Então eu não tinha tempo, então eu estudava só de madrugada, três horas tava eu deitada com o lampião na cabeceira da cama estudando (...) nós estudávamos a luz de vela, lamparina, lampião, a gente as vez ia pra escola cedo, com o nariz tudo preto, sabe, do lampião (...).

No decorrer deste período dos 11 aos 17 anos, ela mora de favor e trabalha como doméstica para poder estudar, enfrenta muitas dificuldades inerentes a sua condição social é quando decide se casar para mais uma vez promover mudanças. Experiências vividas que hoje são parte de uma reflexão como ela aponta aqui,

Não tinha salário, na época a gente trabalhava a troco de comida, dava calcinha velha pra gente, tem tudo isso hoje imagina que hoje eu entendo, eu sei tudo, eu estudei e falo meu Deus, sutiã velho, calcinha velha, tudo ela dava pra mim e a troco de comida por que eu queria estudar, meu sonho era estuda e até hoje eu estudo.

Para por em termo este debate, retornamos a leitura de Bassanezi, quando a autora chama atenção para o fato de que juntamente com a inserção da mulher no mercado de trabalho, o desenvolvimento econômico também contribui para o aumento do nível de escolaridade feminina. Em conformidade com a autora, "a educação com vistas a um futuro profissional e, consequentemente, o investimento em uma carreira eram bem menos valorizados para as mulheres que para os homens" (2004: 625) e a persistência desta diferença estava com as bases calcadas na distinção social do feminino e masculino, aos papeis sociais e a capacidade.

Histórias de superação que se entrelaçam e convergem para uma experiência única, vividas por estas mulheres no período das enchentes. Quando o nível das águas, na enchente de 1979 atingiu 9,16 metros e a cidade ficou toda tomada pelas águas, fez-se necessário que toda a população fosse deslocada para um espaço provisório, um alojamento improvisado pela Defesa civil, denominado pela população como "cidade de lona". 1

\footnotetext{
${ }^{1}$ Como ficou conhecido o local para onde foram levados os desabrigados pela enchente. Eram barracas de lona fornecidas pelo exército e Defesa civil. Localizavam-se nos km 6,7, 8. Eram nas cores preta (1979) e verde (1982).
} 
Neste período muitas famílias mudaram para cidades próximas como Jardim e Bela Vista e mesmo pra capital em Campo Grande, MS, sendo que muitos não retornaram após as enchentes e a construção do dique de contenção das águas. Em 1980, devido ao resíduo da enchente anterior, houve nova elevação do nível do Rio na parte sul da cidade, atingindo $20 \%$ da população, mais especificamente as populações ribeirinhas que foram deslocadas para o km 7. Em 1982, ocorreu a maior das enchentes que se viu em Porto Murtinho atingindo a marca de 9,72 metros. A experiência de deslocamento de 1979 possibilitou uma maior agilidade no atendimento à população que novamente se vê abrigada na "Cidade de Lona". A cidade está tomada pelas águas, fica quase que totalmente submersa. Novo êxodo, mas desta vez pouco significativo.

Ambas, Norma Meza Pereira e Ninfa Avelar Ayub narram os fatos que nortearam seu cotidiano no período em que sucedem as enchentes e as dificuldades por elas enfrentadas quando no nascimento de suas filhas. Esta é a narrativa de Dona Norma quando fala do nascimento de sua segunda filha:

Na terceira esta de [19]82 a gente, é foi muito ruim pra nos justamente no dia que entrou água na minha casa que eu tive a Renata, e já o hospital dentro d'água e eu fui fazer uma cirurgia, eu fiz cesárea e ai tive que fazer a laqueadura também e foi muito ruim pra mim, por que imagina você naquela situação você ta dentro d'água os médicos de bota fazendo cirurgia em você, dentro d'água, eu desci naquela água pra sair (...) e eu fui morar num barraco, fizeram pra mim um barraquinho lá do lado da casa do meu sogro (...) voltei tava baixando a água, as primeiras casas que saíram da água também foi a minha eu mandei arruma tudo limpa e voltei ainda tinha água na cidade, mas eu morava assim sem luz sem água.(PEREIRA, 2008)

Sua narrativa é entrecortada de silêncios, de olhares que buscam um ponto de apoio para estas reminiscências que povoam o presente momento. Esta mulher que tão avidamente defende a preservação do meio ambiente e do patrimônio histórico da cidade, que reclama pelo respeito à diversidade étnica e sócio cultural, parece diante de um emaranhado de emoções tão singulares e tão angustiantes ao mesmo tempo. Refugia-se na paisagem que contempla através da janela, mas suas mãos estão agitadas e seu corpo experimenta as mesmas sensações quando no parto da filha.

A narrativa de Dona Ninfa Avelar, é marcada por muitos questionamentos É importante atentar para um ponto em que ela ressalta:

(...) casei com 17 anos por causa de que, não era assim amor não era nada, era necessidade né, era necessidade, eu falo pra todo mundo hoje, até pra 
minha filha tudo, aí aprendi a como diz, gostá do meu marido, a gente começou a namorar depois de casado que ele morava em fazenda.

Diante desse fato, ela ri e ri sem medo de expor a sua condição na época de seu casamento, isso se confirma quando acrescenta que "não tinha nada" e que "tinha muita vergonha de falar pro noivo que não tinha condições nem de comprar a roupa do casamento." Seus pais não tinham condições financeiras e, o pai foi contra o casamento cuja alegação era considerá-la nova demais para o casamento. Por iniciativa da patroa, que fala como noivo e o mesmo adquire todo o enxoval para o casamento incluindo o vestido da noiva. Para esta mulher, as dificuldades estão aí e a cada novo desafio, acredita que renasce mais forte e pronta para recomeçar.

Ela recorda do parto da filha ela nos dirige um questionamento e também se pergunta: "Como foi que passei por tudo isso?" No dia anterior, quando fui a casa dela para conhecê-la e marcar um horário para a entrevista, ela contou do nascimento da filha Aline. Um parto difícil e das dificuldades pelas quais passou. Quando na entrevista, ela narra:

Ah! Esse parto foi demais. O quartel inteiro veio aqui vê se me convencia a
me tirar daqui, pelo menos me leva pelo menos até a cidade de lona que
tinha um posto de saúde lá e tinha um médico atendendo lá. Mas saí da
minha casa pra ir lá ter um, aí eu pensei na época, e falei bom se eu for
morrer, vou morre aqui ou lá onde for (...).(AYUB, 2008)

Quando ela fala que o parto foi demais, não é no sentido de exuberância, mas da epopeia que foi. Ela estava sentindo muitas dores e não queria sair da casa onde morava, mesmo com a água subindo e sabendo do perigo que isso significava tanto para ela quanto para a criança. Ainda assim, decidiu ficar e recebeu apoio da equipe médica do exército. Ela assim prossegue quando descreve as condições em que o parto foi realizado, "Nada, a luz de vela" e nos conta como foi improvisada a incubadora para o bebê que nasceu prematuramente. Segundo ela, estava muito frio e úmido e a preocupação era aquecer o bebê, mas para isso se fazia necessário um carrinho para que a incubadora fosse improvisada. Carrinho este que o marido conseguiu junto aos desabrigados na cidade de lona. Ela baixa os olhos e fala: "a gente não tinha. Ai ele foi e arrumo o carrinho, trouxe, ai pediu dois botijão de gás com aquela lamparina de gás por que não tinha energia, tinha que ligá alguma coisa e aquece”, e continua "Ai ele botou aquela lamparina dos dois lado aqui em cima da criança, no carrinho, sem pode tira de lá, só tirava rapidinho pra trocá, pra e alimentá. O que que era o alimento? Uma gotinha de suco de cenoura." 
Notemos que a entrevista em si, vem carregada de "códigos" que se apresentam de várias maneiras. Não posso negar a pertinência das palavras de Eudes Leite quando salienta que cabe ao pesquisador, "reconhecer que a narrativa oral possui um conjunto paralelo de acessórios e complementos. Gestos, olhares, ambientes, expressões faciais fazem parte do que o entrevistado narra e, ao mesmo tempo, esses componentes trabalham para garantir o êxito da narrativa" (2003:129). Observações estas, suficientes para mostrar que aquela mulher que está diante de nós, enquanto pesquisadores estão ali se revelando, ou seja, está expondo a sua identidade, a sua história que contém fragmentos ou o todo das experiências vividas, que, para ela, constituem-se a sua memória. O que significa que ocorre uma seleção de fatos, detalhes e acréscimos que contribuem para a continuidade dessa memória. Imagens e palavras que tentam significar aquele instante, dar um sentido ao que está sendo dito, como forma de evidenciar determinados aspectos por deveras, são inexplicáveis apenas por palavras, com os quais ele recria a experiência descrita.

Se considerarmos que a história oral está vinculada ao passado, as memórias sejam individuais e/ou coletivas, percebemos que as memórias não são iguais ou estruturadas, estas são elaboradas socialmente, mas é relevante aqui atentar para o que Portelli salienta quando aponta para o fato de que mesmo sendo as memórias estruturadas socialmente, somente os seres humanos são capazes de armazenar lembranças. Ainda, segundo o autor, "a memória é um processo individual, que ocorre em um meio social dinâmico, valendo-se de instrumentos socialmente criados e compartilhados." (1997:16)

Neste contexto, as narrativas das mulheres e o relato das experiências por elas vividas, podemos dizer que é continuamente construída através do processo de rememoração. A cada momento, reformulamos as lembranças de acordo com o impulso recebido, ou seja, de acordo com a experiência do momento presente. Em conformidade com Raphael Samuel "a memória é historicamente condicionada, mudando de cor e forma de acordo com o que emerge no momento." E prosseguindo, o autor acrescenta, que a memória "porta a marca da experiência, por maiores mediações que ela tenha sofrido." Para o autor, bem como a história, "a memória é inerente e revisionista, e nunca é tão camaleônica como quando parece permanecer igual." (1997:44)

Nosso contato com estas mulheres possibilitou uma análise quanto à presença marcante das mesmas no período de 1970-1990 quando ocorrem as enchentes. O momento é de mobilidade e, as mulheres atuaram em várias frentes, mesmo desabrigadas, elas se mantinham atuantes na distribuição e nos preparativos dos alimentos na cozinha coletiva; no 
cadastramento e seleção das famílias para receberem roupas, calçados e cobertores; no trato com as crianças e na organização das festas que não deixaram de acontecer, mesmo no alojamento. Elas atuam e organizam os espaços, são alvos de querelas e atritos familiares. Estas mulheres têm sua privacidade exposta. Os banhos são coletivos e muitas não estão habituadas a expor o corpo, o que causou muitos constrangimentos. Conhecedoras da natureza eram as responsáveis pelo preparo dos inúmeros chazinhos que ajudaram muita gente enfrentar as noites frias e úmidas do alojamento.

Um fato bastante curioso que envolve a distinção entre o publico e o privado, fica latente no fato narrado pela senhora Conceição que quando teve que deixar sua casa, segundo ela, não quis deixar pra trás seus vasos de samambaia. Ela os levou para o acampamento e decorou o que ela chama de "varanda" da casa improvisada em cima de uma carreta de trator. Tal fato virou manchete dos jornais, onde se lia que a mulher do secretário de obras da prefeitura, enchia de samambaias a casa enquanto as pessoas padeciam flageladas pela enchente. Fato este que trouxe implicações e exigiu explicações. É o publico e o privado que não encontravam a devida distinção no espaço improvisado em função das enchentes.

Neste contexto, o gesto de rememorar, trás em si intrínsecos interesses, seja do individuo seja do grupo em que está inserido. Com o passar do tempo, as lembranças vão sendo resignificadas e a memória se apresenta em constante reconstrução. Para estas mulheres, os momentos difíceis pelos quais passaram, hoje podem até trazer algum resquício de sofrimento, mas é visto com simplicidade e gera boas risadas nos momentos em que as famílias estão reunidas. Esta é uma característica, segundo dito por muitas destas mulheres, dos habitantes da região, inerentes ao ambiente. É importante frisar que Porto Murtinho é um centro urbano no Pantanal e conserva muitas características do ambiente e da região fronteiriça.

A proposta inicial deste texto foi contemplar a presença das mulheres, sua relação com o meio-ambiente, seu cotidiano e as privações no período das enchentes em Porto Murtinho. Considerando a importância de se compreender historicamente as estratégias construídas para a sobrevivência em áreas que tradicionalmente foram afetadas pelas enchentes, como é o caso de Porto Murtinho, na fronteira com o Paraguai. Consideramos de fundamental importância destacar as relações de gênero e poder que e seus desdobramentos neste período. As possibilidades de novas pesquisas e novos enfoques sobre a presença das mulheres nas enchentes do Pantanal deixam a certeza de que atingimos o objetivo inicialmente proposto. Isso posto, como um fator de mudanças, da busca de novas estratégias e da releitura das 
relações entre a natureza no Pantanal e a atuação da mulher na preservação do meio ambiente e as representações construídas historicamente.

\section{Fontes Orais}

Conceição Aparecida Montanheri. Entrevista em 22 de agosto de 2009, por Ilsyane do Rocio Kmitta. Porto Murtinho/MS.

Ninfa Amada Ovelar Ayub. Entrevista em 21 de agosto de 2008, por Ilsyane do Rocio Kmitta. Porto Murtinho, MS.

Norma Meza Pereira. Entrevista em 20 de agosto de 2008, por Ilsyane do Rocio Kmitta Porto Murtinho, MS.

\section{Referências Bibliográficas}

ALBERTI, Verena. Fontes Orais. Histórias dentro da História. In: Fontes Históricas. Carla Bassanezi Pinski (org.). São Paulo: Contexto, 2005.

ALBERTI, Verena. Ouvir Contar: textos em História Oral. Rio de Janeiro: Ed. FGV, 2004.

BASSANEZI, Carla. Mulheres dos Anos Dourados. In: História das Mulheres no Brasil. São Paulo: Ed. Contexto, 2004.

CERTEAU, Michel de. A invenção do cotidiano: artes de fazer. 6ª ed. Petrópolis: Vozes, 2001.

119. A Operação Historiográfica. In: . A escrita da história. Rio de Janeiro: Forense, 1982. pp. 65-

CHARTIER, Roger. O mundo como representação. Estudos Avançados, vol. 5, n. ${ }^{\circ}$ 11, jan./abr. 1991, pp. 173191.

. Poderes e limites da representação. Marin, o discurso e a imagem. In: À beira da falésia: a história entre incertezas e inquietude. Trad. Patrícia Chittoni Ramos. Porto Alegre: Ed. Universidade/UFRGS, 2002, p. 163-180.

COLLING, Ana Maria.Tempos diferentes, discursos iguais: a construção do corpo feminino na história. Dourados, MS: Ed. UFGD, 2014.

CORREA. Lúcia Salsa. História e Fronteira: o sul de Mato grosso 1870-1920. Campo Grande: UCDB, 1999.

CUNHA, L. de O. Significados múltiplos das águas. In: DIEGUES, A.C. (org.) A Imagem das águas. São Paulo: Hucit5ec, NUPAUB/USP, 2000.

DIEGUES, A.C. (org.) A Imagem das águas. São Paulo: Hucit5ec, NUPAUB/USP, 2000.

KMITTA, I. R. Experiências vividas, naturezas construídas: Enchentes no Pantanal (Porto Murtinho 19701990). 2010. Dissertação (Mestrado em História)- Faculdade de Ciências Humanas, Universidade Federal da Grande Dourados - UFGD, Dourados, MS.

LEITE, Eudes Fernando. Narrativas e Imagens: A busca do passado nas palavras e nos gestos. In: Fronteiras. Revista de História/ Universidade Federal de Mato Grosso do Sul. V.7 n.13 -2003 Ed. UFMS.

MONTYSUMA, Marcos Fabio Freire. Gênero e meio ambiente: uma invisibilidade das mulheres na construção da floresta na Amazônia. In: História, Natureza e Território. Ed. UNIVALE, 2008.

ORTNER. Sherry Beth. Está a mulher para o homem assim como a natureza para a cultura? In: A mulher, a cultura e a sociedade. Rio de Janeiro: Paz e Terra, 1979.

PERROT, Michelle. As mulheres ou os silêncios da história. Bauru, EDUSC, 2005.

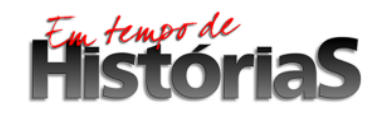


Os excluídos da História: Operários, mulheres e prisioneiros. Rio de Janeiro: Paz e Terra, 1988.

POLLAK, Michel. Memória e Identidade Social. Estudos Históricos. Rio de Janeiro, v.5, n. 10, 1992.

PORTELLI, Alessandro. Tentando aprender um pouquinho: Algumas reflexões sobre a ética na História Oral. Projeto História. Revista do Programa de Estudos Pós-Graduados de História/PUC, São Paulo: (15) abril, 1997

SAFFIOTI, Heleieth Iara Bongiovani. A mulher na sociedade de classe: mito e realidade. Petrópolis: Vozes, 1976.

SAMUEL, Raphael. Teatros de Memória. Projeto História, São Paulo (14), fev. 1997.

SCOTT, Joan. Género e historia. México: UAM, 2008. 99.

Gênero, uma categoria útil de análise histórica. Educação \& Realidade. Jul-Dez. 1995, v. 20, (2), p. 71-

TOSI, Lucia. Mulher e Ciência. A Revolução Cientifica, A caça as bruxas e a Ciência Moderna. Cadernos pagu (10) 1998: pp.369-397. 